\title{
Penyakit Kimura Parotis
}

\section{Pandu Putra Harsarapama, Yussy Afriani Dewi, Bambang Purwanto, Agung Dinasti Permana}

\author{
Departemen Ilmu Kesehatan Telinga Hidung Tenggorok Kepala Leher, \\ Fakultas Kedokteran Universitas Padjadjaran / \\ Rumah Sakit Umum Pusat dr. Hasan Sadikin \\ Bandung
}

\begin{abstract}
Abstrak
Penyakit kimura adalah kelainan inflamasi kronis, ditandai adanya limfadenopati atau massa jaringan lunak subkutan, tanpa nyeri, sering mengenai daerah kepala dan leher. Pertama kali dilaporkan di Cina pada 1937, disebut limfogranuloma hiperplastik eosinofilik. Tahun 1948, ditemukan keterlibatan komponen vaskular oleh Kimura, sehingga disebut Penyakit Kimura. Rasio perbandingan laki-laki dibandingkan wanita adalah 3.5-9 : 1. Insidensi usia adalah 20-30 tahun. Kasus remaja laki-laki berusia 17 tahun datang ke Poliklinik THT-KL RSHS Bandung dengan keluhan benjolan leher sebelah kiri, daerah parotis, kelenjar getah bening level $\mathrm{Ib}$ dan II. Keluhan dirasakan sejak 2 bulan sebelumnya. Awalnya benjolan berukuran diameter $5 \mathrm{~mm}$, membesar sampai sebesar $90 \mathrm{~mm}$, mudah bergerak dan tidak nyeri pada perabaan. Metode pemeriksaan laboratorium darah menunjukkan nilai eosinofil $22 \%$, protein $9.4 \mathrm{gr} / \mathrm{dL}$, dan serum $\mathrm{IgE} 3,8 \mathrm{mg} / \mathrm{dL}$. Ultrasonografi leher menunjukkan massa solid yang dominan dengan bagian kistik di dalamnya yang mengobliterasi sebagian kelenjar parotis kiri. Pemeriksaan biospi jarum halus menunjukkan karsinoma parotis kemungkinan suatu mukoepidermoid. CT-Scan menunjukkan gambaran massa solid di daerah pre-parotis kiri dan lesi hipodens multipel bulat di daerah pre-parotis dan pre-aurikula kiri. Hasil pemeriksaan histopatologis pasca operasi menunjukkan gambaran penyakit kimura parotis. Diskusi pasca operasi, diberikan radioterapi dengan dosis 30 Gy, dilakukan kontrol selama satu tahun, tanpa terapi farmakologis, tidak ditemukan angka kekambuhan penyakit.
\end{abstract}

Kata Kunci : Kimura, Parotis, Radioterapi

\section{Parotid Kimura Disease}

\begin{abstract}
Kimura Disease is a rare chronic inflamation characterized by painless lympahadenopathy or subcutaneous soft tissue mass ocasionally affected head and neck region. First reported in China at 1937, termed "Hyperplastic Eosinophilic Lymphogranuloma". At 1948, microscopic study by Kimura showed that vascular component involvement, then named as Kimura Disease. Males are more prevalent then females with incidence the of 3.5-9:1 and at age of 20th-30th. Case a young male outpatient aged 17th came to ORL-HNS Clinic Hasan Sadikin Hospital Bandung with chief complaint of painless swelling at left neck region, located at parotid region, neck lymph node level Ib dan II. The patient has been having this complaint for about 2 months. The nodule size that was initially $5 \mathrm{~mm}$ diameter, is now getting bigger and has reached $90 \mathrm{~mm}$ in diameter, the nodule is mobile and painless. Methods blood laboratory showed that eosinofil: $22 \%$, protein: $9.4 \mathrm{gr} / \mathrm{dL}$, and serum IgE value: $3.8 \mathrm{mg} / \mathrm{dL}$. Neck ultrasonography showed that a solid dominant mass with a cyst inside, obliterated the left parotid gland. Fine needle aspiration biopsy revealed that parotid carcinoma suspected mucoepidermoid. CT-Scan result revealed a solid mass at left pre-parotid and multiple hipodense lesion at left pre-parotid and pre-auricle. The result post-operative histopathologic examination result showed a kimura disease appearance. Discussion radiotherapy 30 Gy has been given after the surgery. Follow-up in 1 year period, without pharmacologic therapy, showed that no relapsing mass.
\end{abstract}

Keywords : Kimura, Parotid, Radiotherapy

Korespondensi:

Pandu Putra Harsarapama

Departemen Ilmu Kesehatan Telinga Hidung Tenggorok Kepala Leher, Fakultas Kedokteran Universitas Padjadjaran / Rumah Sakit Umum Pusat dr. Hasan Sadikin Bandung

Jl. Prof. Dr. Eyckman No. 38 Bandung 40161

Mobile : 089624429121

Email : pandup1402@gmail.com 


\section{Pendahuluan}

Penyakit Kimura adalah suatu kelainan inflamasi kronis, ditandai dengan limfadenopati tanpa nyeri atau massa jaringan lunak subkutan yang mengenai daerah kepala leher. Pertama kali dilaporkan di Cina pada 1937, disebut limfogranuloma hiperplastik eosinofilik. Pada Tahun 1948, ditemukan keterlibatan komponen vaskular oleh Kimura, sehingga disebut Penyakit Kimura. ${ }^{1}$

Dilaporkan kurang lebih 200 kasus penyakit kimura di seluruh dunia, semenjak ditemukan pertama kalinya secara histopatologis. ${ }^{2}$ Kasus ini lebih sering ditemukan pada laki-laki dibandingkan wanita dengan perbandingan 3.5 - 9:1 dan insidensi usia adalah 20-30 tahun. Kasus ini sering mengenai ras Asia, berhubungan dengan faktor genetik dan kultural. ${ }^{3}$ Penyakit kimura ditandai oleh gambaran hipereosinofilia dan peningkatan serum imunoglobulin-E (IgE) ${ }^{1}$

Gejala klinis didapatkan benjolan disertai rasa gatal, unilateral atau bilateral, terkadang terdapat adenopati satelit, tanpa keluhan nyeri di daerah kepala dan leher. ${ }^{3,5}$ Pembedahan masih merupakan pilihan terapi utama, sedangkan radioterapi juga memberikan hasil yang baik. ${ }^{1}$ Prognosis penyakit kimura cukup baik, belum pernah dilaporkan adanya transformasi menjadi keganasan.,

\section{Laporan Kasus}

Seorang remaja laki-laki berusia 17 tahun datang ke Poli Onkologi Bedah Kepala dan Leher Ilmu Kesehatan THT-KL RSHS Bandung dengan keluhan benjolan pada leher sebelah kiri, daerah parotis dan kelenjar getah bening level Ib dan II terlihat pada gambar 1. Keluhan sudah dirasakan sejak 2 bulan sebelumnya. Awalnya benjolan hanya berukuran diameter $5 \mathrm{~mm}$, membesar sampai sebesar $90 \mathrm{~mm}$, mudah bergerak dan tidak ada rasa nyeri pada perabaan. Terdapat keluhan gatal yang disertai pembentukan papula pada permukaan kulit benjolan. Tidak ditemukan gangguan pendengaran, paresis nervus fasialis, demam dalam jangka waktu lama, kehilangan berat badan progresif, dan kehilangan nafsu makan. Tidak ada riwayat infeksi sebelumnya pada organ kepala dan leher, riwayat merokok atau konsumsi alkohol, dan penyakit serupa pada keluarga.

\section{Metode}

Metode pemeriksaan yang diakukan pada kasus ini adalah pemeriksaan laboratorium darah, ultrasonografi leher, pemeriksaan CT-Scan leher, pemeriksaan biopsi jarum halus, dan pemeriksaan biopsi spesimen operasi. Pemeriksaan laboratorium darah dalam batas normal, kecuali nilai eosinofil $22 \%$, imunoglobulin-E $3.8 \mathrm{mg} / \mathrm{dL}$, dan protein $9.4 \mathrm{gr} / \mathrm{dL}$. Pemeriksaan ultrasonografi leher, menunjukkan massa solid yang dominan dengan bagian kistik di dalamnya yang mengobliterasi sebagian kelenjar parotis kiri dan gambaran vaskularisasi suspek massa primer parotis kiri. Pemeriksaan CT-Scan menunjukkan gambaran massa solid di daerah pre-parotis kiri dan lesi hipodens multipel bulat di daerah pre-parotis dan pre-aurikula kiri, curiga suatu pembesaran kelenjar getah bening.

Pemeriksaan biospi jarum halus, menunjukkan hasil karsinoma parotis kemungkinan suatu mukoepidermoid, untuk kemudian direncanakan parotidektomi total. Pada temuan operasi, didapatkan keterlibatan saraf fasialis dalam massa parotis, sehingga hanya dilakukan parotidektomi superfisial. Pemeriksaan histopatologis pasca operasi menunjukan gambaran folikel eosinofil dengan sentrum germinativum yang tampak nyata dan hiperemis, infiltrasi sel radang eosinofil yang nyata, terbentuknya abses eosinofil (mikroabses), hiperemis interfolikuler dan banyak jaringan ikat didalamnya (reactive follicular hyperplasia) menunjukan gambaran penyakit kimura.
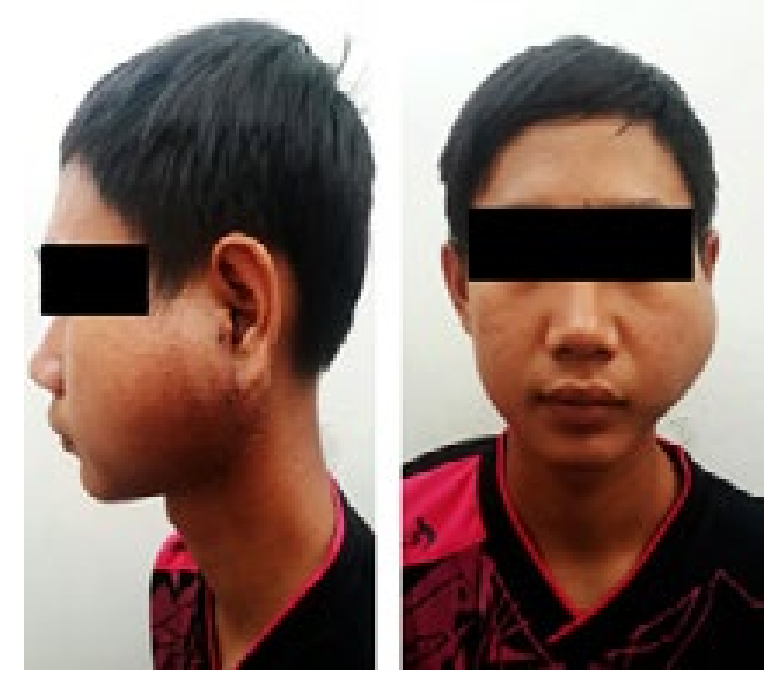

Gambar 1 Gambaran Klnis sebelum pembedahan dan radioterapi 


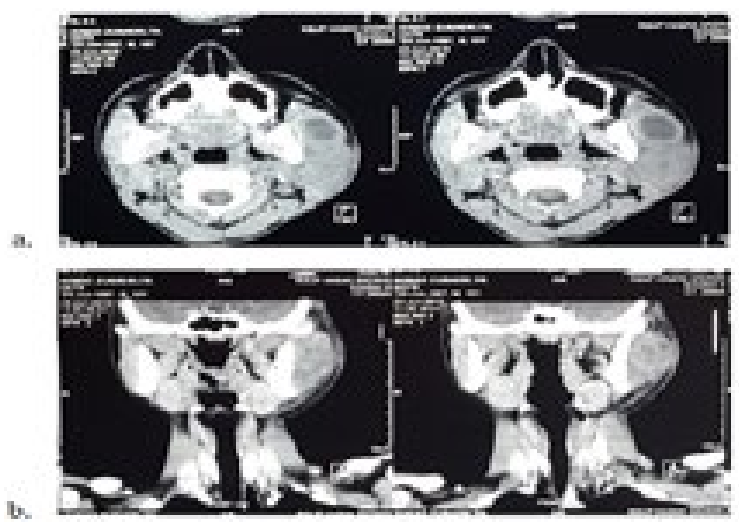

Gambar 2 CT-Scan Leher A. Potongan aksial. B. Potongan koronal

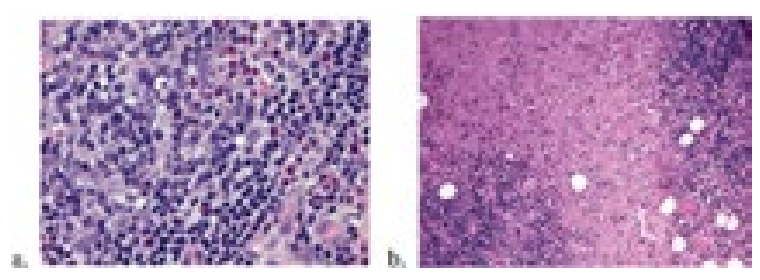

Gambar 3 Histoplatologis penyakit kimura pasca operasi. A. folikel eosinofil dengan sentrum germinativum. B. Infiltrasi Eosinofil

\section{Hasil}

Pasca operasi, direncanakan untuk dilakukan radioterapi sebesar 30 Gy, yang akan diberikan dalam 30 hari, dengan fraksionasi 1 Gy per fraksi, sekali dalam sehari, lima hari dalam seminggu, sehingga total dosis radioterapi adalah 30 Gy.

Pasca radioterapi diberikan, terjadi remisi komplit penyakit. Secara klinis, tidak ada keluhan munculnya kembali benjolan pada leher, pemeriksaan fisik leher menunjukkan tidak didapatkan massa, dan pemeriksaan USG tidak menunjukkan adanya massa yang tersisa.

Pasien kemudian dilakukan kontrol selama satu tahun, tanpa terapi farmakologi. Anamnesis, pemeriksaan fisik, dan pemeriksaan penunjang pada bulan ke-6 dan ke-12 menunjukkan tidak didapatkan adanya rekurensi (Gambar 4 dan 5).
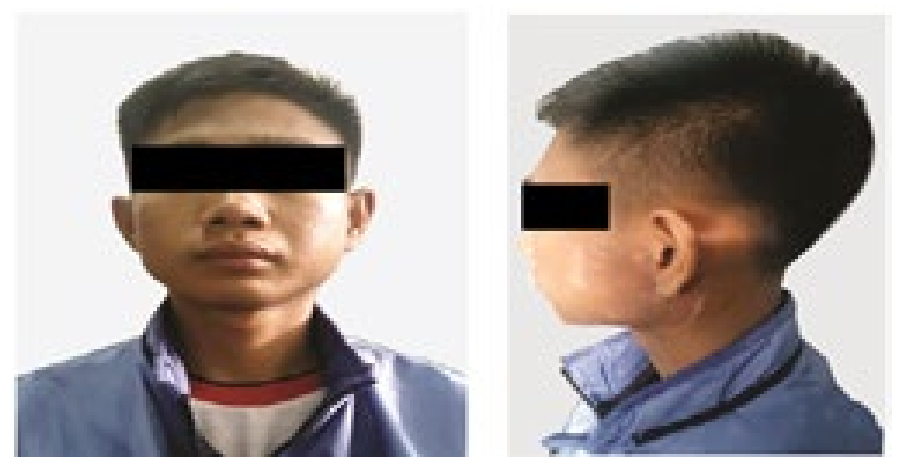

Gambar 4 Gambaran Klinis pasca dilakukan pembedahan dan radioterapi (Kontrol 6 Bulan)
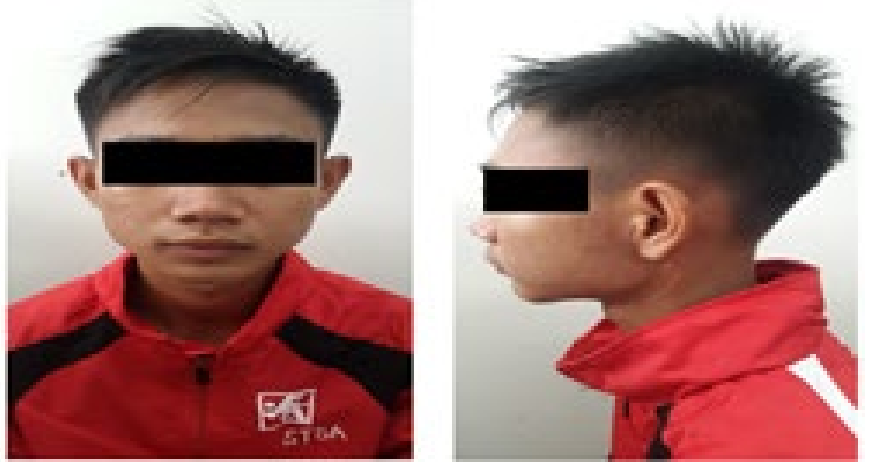

Gambar 5 Gambaran Klinis pasca dilakukan pembedahan dan radioterapi (Kontrol 1 Tahun) 


\section{Pembahasan}

Penyakit kimura adalah suatu keadaan penyakit inflamasi kronik lokal yang ditandai dengan benjolan atau nodul jaringan lunak subkutan yang disertai dengan adanya limfadenopati pada 30$40 \%$ kasus, biasanya asimetris, dan paling sering mengenai daerah kepala dan leher, terutama preaurikula, submandibula, kavum oris, laring, dan kelenjar parotis. ${ }^{3,7,8}$

Gambaran klinis yang khas adalah adanya massa yang membesar secara perlahan dan biasanya disertai rasa gatal pada permukaan kulit. Insidensi usia adalah 20-30 tahun, dengan usia rata-rata adalah 22.8 tahun, jenis kelamin laki-laki dan keturunan ras asia lebih berisiko terhadap penyakit ini. ${ }^{3,4,6,9}$ Pada kasus ini, terjadi pada laki-laki muda Asia berumur 17 tahun. Hasil pemeriksaan didapatkan suatu benjolan unilateral pada daerah parotis dan kelenjar getah bening level $\mathrm{Ib}$ dan II, disertai rasa gatal, tanpa disertai rasa nyeri, menunjukkan salah satu gejala dari penyakit kimura. Pemeriksaan laboratorium darah didapatkan hasil dalam batas normal, kecuali nilai eosinofil $22 \%$, imunoglobulin-E $3.8 \mathrm{mg} / \mathrm{dL}$, dan protein $9.4 \mathrm{gr} / \mathrm{dL}$. Pemeriksaan ultrasonografi menunjukkan massa solid yang dominan dengan bagian kistik di dalamnya yang mengobliterasi sebagian kelenjar parotis kiri dan gambaran vaskularisasi suspek massa primer parotis kiri. Pemeriksaan CT-Scan menunjukkan gambaran massa solid di daerah pre-parotis kiri dan lesi hipodens multipel bulat di daerah pre-parotis dan pre-aurikula kiri, curiga suatu pembesaran kelenjar getah bening.

Patogenesis penyakit ini adalah terdapat interaksi Sel T-Helper 1 (Th1) dan T-Helper 2 (Th2) yang menyebabkan produksi berlebih dari sitokin IL-4 dan gangguan dalam proliferasi Sel $\mathrm{T}$ yang mengakibatkan pembentukan IL-5, keduanya merangsang produksi eosinofil yang meningkat. Titer protein sitotoksik, protein kationik eosinofilik dan protein dasar mayor yang terdapat dalam granula eosinofil biasanya tinggi. Penyakit autoimun, paparan stimulasi antigen saat infeksi virus, parasit, jamur (kandida), riwayat trauma lokal, bahkan sampai gigitan serangga disebut menjadi salah satu hipotesis munculnya penyakit kimura, tetapi seluruh teori tersebut masih harus dibuktikan kebenarannya. ${ }^{5,10,11}$

Penyakit kimura sering disalahartikan sebagai suatu keganasan leukemia limfositik akut, limfoma sel-T, sarkoma kaposi, penyakit hodgkin atau tumor parotis. Penyakit kimura juga sering dianggap sebagai suatu kelainan hiperplasia angioloimfoid dengan eosinofilia $(A L H E)$, akan tetapi pemeriksaan histopatologis membedakan secara jelas kedua tipe kelainan ini. ${ }^{12,13}$ Pada penyakit kimura, gambaran nodul limfoid dengan infiltrat eosinofil dan abses eosinofil jelas terlihat. Proliferasi vaskuler terkadang terlihat, ditandai dengan adanya dinding vaskuler yang tipis. Sedangkan pada $A L H E$, tidak didapatkan infiltrat eosinofil yang nyata dan tidak adanya abses eosinofil. Pada penyakit kimura, laki-laki lebih sering terkena, sedangkan pada $A L H E$, wanita lebih sering terkena. ${ }^{14}$

Gambaran histopatologis penyakit kimura ditandai dengan adanya gambaran hiperplasia folikular jaringan limfoid, infiltrasi eosinofilia daerah interfolikular, lisis folikular, dan terbentuk mikroabses. Granuloma yang terbentuk terdapat infiltrasi dari eosinofil, limfosit, sel plasma, dan histiosit. Terlihat sklerosis dan fibrosis jaringan, serta proliferasi dari vaskular dengan dinding endotel yang tipis. Pemeriksaan imunofloresensi menunjukan deposit IgE, IgG, IgM, dan fibrinogen. ${ }^{3,15}$

Pemeriksaan biopsi aspirasi jarum halus menunjukkan suatu gambaran mukoepidermoid yang menandakan keganasan. Sesuai dengan teori yang ada, diagnosis banding penyakit kimura adalah suatu keganasan, sehingga pemeriksaan spesimen biopsi inti memegang peranan yang penting dalam penegakkan diagnosis. Spesimen biopsi inti pasca operasi menunjukkan adanya gambaran folikel limfoid dengan sentrum germinativum yang tampak nyata dan hiperemis, infiltrasi sel radang eosinofil yang nyata, terbentuknya abses eosinofil (mikroabses), hiperemis interfolikuler dan banyak jaringan ikat didalamnya (reactive follicular hyperplasia) yang merupakan gambaran histoptologis penyakit kimura. Pemeriksaan radiologi penyakit kimura dapat menyerupai kondisi penyakit kronis dan keganasan seperti tuberkulosis dan limfoma. Pada kasus keterlibatan kelenjar saliva, diagnosis banding dengan adenokarsinoma, adenoma, dan lesi metastatik harus dipikirkan. Walaupun memiliki kesamaan karakteristik radiologis, pemeriksaan ultrasonografi, CT-Scan dan MRI pre-operatif sangat penting dilakukan untuk menentukan keterlibatan organ lain. ${ }^{16}$

Pemeriksaan CT-Scan pada kasus ini menunjukkan gambaran massa solid di daerah pre-parotis kiri dan lesi hipodens multipel bulat di daerah pre-parotis dan pre-aurikula kiri, sugestif suatu pembesaran kelenjar getah bening sehingga dicurigai ada keterlibatan kelenjar getah bening. Pembedahan masih merupakan pilihan utama, baik itu indikasi terapeutik ataupun diagnostik. Terapi konservatif seperti pemberian steroid secara oral, pernah dilaporkan memberikan efek, tetapi sering terjadi rekurensi. Angka kesuksesan terapi didapatkan pada pemberian konstan steroid dengan dosis rendah, tetapi harus dipikirkan 
pada pasien yang memiliki insufisiensi renal., ${ }^{4,15}$ Cetirizin dilaporkan membantu terjadinya remisi pada kasus ketergantungan steroid, bahkan sampai 6 bulan setelah penghentian steroid. ${ }^{17}$

Siklosporin dengan dosis $5 \mathrm{mg} / \mathrm{KgBB} /$ hari dan pentoksifilin oral pernah dilaporkan memberikan efek pengecilan massa, akan tetapi terjadi rekurensi ketika pemberian dihentikan. ${ }^{18}$ Imunoglobulin intravena pernah dilaporkan memiliki angka bebas massa tumor selama lebih dari 6 tahun. Trans asam retinoat dikombinasikan dengan prednison oral pernah dilaporkan memiliki angka bebas massa tumor selama 1 tahun. ${ }^{19}$ Imatinib dilaporkan pernah menjadi salah satu modalitas terapi pada penyakit kimura, terutama yang disertai dengan sindroma hipereosinofilik, akan tetapi masih butuh penelitian lebih lanjut. ${ }^{20}$

Radioterapi merupakan terapi yang rutin pada penyakit kimura, baik kasus primer, rekurensi, dan persisten. Hareyama melaporkan pemberian dosis radioterapi sebesar 26-30 Gy memiliki respons sebesar $90 \%$, bahkan tanpa terapi pembedahan sekalipun. Pada studi lain menyebutkan bahwa radioterapi dengan dosis 20-45 Gy, lebih efektif jika dibandingkan dengan eksisi lokal atau terapi steroid dengan perbandingan respons $64,2 \%$ : $22,2 \%$. Tidak ada efek samping yang terdeteksi pada selama observasi 65 bulan. ${ }^{21}$

Pada laporan kasus ini, pembedahan dan radioterapi merupakan terapi yang dipilih untuk mencapai remisi komplit serta mencegah rekurensi. Parotidektomi superfisial yang dilanjutkan dengan radioterapi dengan dosis 30 Gy, memberikan hasil berupa remisi komplit dan tidak ditemukannya rekurensi dalam rentang waktu kontrol satu tahun.

Sebagai kesimpulan, penyakit kimura merupakan penyakit yang sangat jarang ditemukan. Sebaiknya dipikirkan dalam diagnosis banding yang muncul pada pasien laki-laki muda ras Asia dengan keluhan benjolan yang tidak nyeri pada perabaan, terdapat pada daerah kepala leher, disertai dengan peningkatan angka eosinofil dan serum imunoglobulin-E. Pemeriksaan histopatologis sangat disarankan untuk penegakan diagnosis. Dibutuhkan penelitian dan observasi lebih lanjut untuk menilai angka rekurensi dan efektifitas serta rasionalitas terapi, mengingat sangat jarangnya penyakit kimura dan banyaknya modalitas terapi yang dapat dilakukan, walaupun pembedahan dan radioterapi masih menjadi terapi utama yang digunakan sampai saat ini.

\section{Daftar Pustaka}

1. Kulkarni N. 2013. Kimura's Disease : A Case Report. International Journal of Medical
Research and Health Sciences. Volume 3, Issue 1, November, Page 179-82.

2. Kumar V, Salini, Haridas S. 2010. Kimura's disease : An uncommon cause of lymphadenopathy. Indian Journal Medicine Pediatric Oncology. 2010. Volume 31, Issue 3, Page 89-90.

3. Fatemah F, Alhassan F A, Sebeih K A, Bastakis J. 2014. Kimura Disease Manifesting as Synchronous Bilateral Parotid Swelling in a Young Middle-Eastern Patient. Hindawi Case Report of Surgery. Volume 2014.

4. Ranka S R, Rajput A, Kantharia C V. 2004. Kimura's disease. Indian Journal of Otolaryngology and Head and Neck Surgery, Vol. 56, No. 1, Page 43-5.

5. Savage N W, Vucicevic B V. 2013. Unilateral intraparotid swelling: a case report of Kimura's disease and review of differential diagnosis. Case reports in Otolaryngology. Volume 3.

6. Haija M A, Hurford M T. 2010. "Kimura disease," Archives of Pathology and Laboratory Medicine. Volume 131, No. 4, Page 650-1.

7. Rajpoot D K, Pahl M, Clark J. 2000. Nephrotic syndrome associated with Kimura disease. Pediatric Nephrology. Volume 14, No. 6. Page 486-8.

8. Tseng C F, Lin $\mathrm{H}$ C, Huang $\mathrm{S}$ C, Su CY. 2005. Kimura's disease presenting as bilateral parotid masses. European Archive of Otorhinolaryngology. Volume 262, Page $8-10$.

9. Punia R P S, Aulakh R, Garg S, Chopra R, Mohan H, Dalal A. 2013. Kimura disease : clinicopathological study of eight cases. The Journal of Laryngology and Otology. Volume 127, Page 170-4.

10. Ortak T, Tekin F, Aksoy E, Kerem A, Uralo`glu M, S,ens“oz O. 2008. Kimura disease: a brief clinical report. European Journal of Plastic Surgery. Volume 31, No. 5, Page 253-7.

11. Prasad B K, Deviprasad R. 2008. Kimura's disease: an unusual case of neck mass. Indian Journal of Otolaryngology and Head and Neck Surgery. Volume 60, No. 4, Page 3535.

12. Biradar A, Patil A, Kotennavar M, Venkatachalaiah M. 2013. Kimura's disease: a case report. Indian Journal of Surgery. Volume 75, No. 1, Page 430-1.

13. Yuen H W, Goh Y H, Low W K, Lim S K. 2005. Kimura's disease: a diagnostic and therapeutic challenge. Singapore Medicine Journal. Volume 46, Page 179-83

14. Khoo B P, Chan R. 2002. Kimura disease: 
2 case reports and a literature review. Cutis. Volume 70, No. 1, Page 57-61.

15. Meningaud J P, Pitak A P, Fourwt P, Bertrand J C. 2007. Kimura's Diaease of the Parotid region: Report of 2 cases and review of the literature. Journal Oral Maxillofacial Surgery. Volume 65, No. 1, Page 134-40.

16. Iwai H, Nakae K, Ikeda K. 2007. Kimura disease: diagnosis and prognostic factors. Otolaryngology-Head and Neck Surgery. Volume 137, no. 2, Page 306-11.

17. Chetrit E B, Amir G, Shalit M. 2005. Cetirizine: an effective agent in Kimura's disease. Arthritis Rheumatology. Volume 53, Page 117-8.

18. Viswanatha B. 2007. Kimura's disease in children: a 9 years prospective study. International Journal Pediatric of Otorhinolaryngology. Volume 71:1521-5

19. Boulanger E, Gachot B, Verkarre V, Valensi F, Brousse N, Hermine O. 2002. All trans retinoic acid in treatment of Kimura's disease. Volume 71, Page 66.

20. Sun Q F, Xu D Z, Pan S H. 2008. Kimura disease: review of the literature. International Medicine Journal. Volume 38, Page 668-72.

21. Hareyama M, Oouchi A, Nagakura H, Asakura K, Saito A, Satoh M, Tamakawa M, Akiba H, Sakata K, Yoshida S, Koito K, Imai K, Kataura A, Morita K. 1998. Radiotherapy for Kimura's disease: the optimum dosage. International Journal of Radiation Oncology Biology Physiology. Volume 40, Page 64751. 